IRSH 5 I (2006), pp. 4I-67 DOI: I0.I0I7/So0208590050023 I 2

(C) 2006 Internationaal Instituut voor Sociale Geschiedenis

\title{
Managing Police Constables and Firefighters: Uniformed Public Services in English Cities, c. $1870-1930^{*}$
}

\author{
SHANE EWEN
}

SumMARY: Using a variety of archival sources, notably personnel records and municipal minute books, this article builds a picture of the work-life histories of rank-and-file police constables and firefighters in the English cities of Birmingham and Leicester, and contrasts the techniques of behavioural control adopted by their employers. By drawing on an expanding literature on the social history of public institutions, the article compares the experience of managing such disciplined and uniformed public services. The article demonstrates that municipal management combined insidious devices for controlling workers' behaviour with consensual and negotiated tactics deployed by workers aware of the tangible material benefits offered by a career in public service. Moreover, by placing the English experience of municipal policing and fire-fighting in an international context by focusing on the visits and writings made by prominent technical and social reformers, the article offers a framework within which comparative research can be undertaken.

\section{INTRODUCTION}

Historians have traditionally examined the responsibilities of English police constables and firefighters without paying attention to their role as blue-collar workers and that of the local authority as their employer. Victorian constables were, according to Robert Storch, the agents of bourgeois capital, a "plague of blue locusts" employed to force workingclass communities in industrial towns to conform to middle-class values of respectability. ${ }^{\mathrm{I}}$ Paradoxically, Whig historians have stressed that constables upheld law and order in a liberal society, their appointment being the rational response to rising crime and social disorder within

\footnotetext{
* The Economic and Social Research Council funded the research on which this article is based. The author is grateful to Martin Daunton, Richard Rodger, Pierre-Yves Saunier, Dieter Schott, Chris A. Williams, and the editors and anonymous referees for their constructive criticism at various stages.

I. R.D. Storch, “'The Plague of Blue Locusts': Police Reform and Popular Resistance in Northern England I840-1857", International Review of Social History, 20 (1975), pp. 61-90.
} 
industrializing and urbanizing England. ${ }^{2}$ Social historians have since identified a middle ground, agreeing that the conflicting and consensual relationships inherent in both interpretations fail satisfactorily to explain the complex relationship between the "new police" and the public. Policing was a combination of both interpretations, with the constable having the power to use coercive methods, but preferring to act by consent within the boundaries of civil society. ${ }^{3}$

Although the fire service has not received anywhere near the level of scholarly attention as the police, those who have studied firefighting have seen its development as a linear progression from an unskilled occupation during the mid-nineteenth century to a skilled profession informed by scientific principles by the interwar years. Changes to the profession were the result of the innovations of "great men", invariably chief fire officers such as James Braidwood and Eyre Massey Shaw. ${ }^{4}$ Histories of firefighting neglect to place the development of a professional culture and the emergence of workers' welfare within a broader socio-economic context. ${ }^{5}$

Only recently have social historians turned their attention to the fire service. Terry Segars, for example, has stressed the importance of examining the service as encompassing a working-class culture. Rather than depending on the actions of "great men", the firefighter's work evolved in a piecemeal manner and, consequently, there was a progressive shift in how ordinary firefighters viewed their role in relation to that of their employers. Modifications to firefighting and the use of technology were interrelated with the growth in urban scale, the demands for improved protection, and the emergence of transnational networks for the circulation of technical knowledge within civil society, yet the traditions of discipline and servitude were pivotal in moulding a professional service. $^{6}$

2. J.J. Tobias, Crime and Industrial Society in the Nineteenth Century (Harmondsworth, 1967); Thomas Critchley, History of Police in England and Wales (London, 1978).

3. Clive Emsley, The English Police: A Political and Social History, 2nd edn (London, 1996); Carolyn Steedman, Policing the Victorian Community (London, I980); D.J.V. Jones, Crime, Protest, Community and Police in Nineteenth Century Britain (London, 1982). Recent work has re-emphasized the class conflict inherent within urban policing: Mike Brogden, On the Mersey Beat: Policing Liverpool between the Wars (Oxford, 1991).

4. Braidwood was chief officer of Edinburgh Fire Engine Establishment (1 823-1833), Britain's first full-time municipal brigade, and was the first superintendent of the private London Fire Engine Establishment (I833-I86I). He was replaced by Shaw who then commanded the Metropolitan Fire Brigade from its inception (I865-I89I).

5. Geoffrey Blackstone, History of the British Fire Service (London, 1957); Sally Holloway, London's Noble Fire Brigades, 1833-1904 (London, 1973); Ron Cox, Oh, Captain Shaw! (London, 1984); Brian Henham, True Hero: The Life and Times of James Braidwood (Romford, 2000).

6. Terry Segars, "The Fire Service: The Social History of a Uniformed Working-Class Occupation" (Ph.D., University of Essex, I989); S. Ewen, "The Internationalization of Fire 
Recent research has repositioned the worker within the historic literature on these public services, although there has been no attempt to compare the experiences of constables and firefighters as disciplined and uniformed workers, especially in an urban context where the creation of "dynamic and complex" landscapes in English, continental, and north American cities posed organizational and operational challenges for policing and fire protection during the late nineteenth and early twentieth centuries. 7 Being locally controlled and funded (or partly in the case of the police), in most instances by watch committees established in I835, English police and fire services formed part of a broader strategy to regulate city spaces and control the negative externalities associated with urbanization. Indeed, alongside the possession of property and participation in a network of voluntary associations, the ordering of civil society was one of the common objectives that united the property-owning middle classes during the nineteenth century. ${ }^{8}$ If, therefore, it made practical sense for a local authority to establish a police force or fire brigade to protect a city's social and economic infrastructure, it was equally important to recruit and retain a workforce that would secure more than the tacit consent of local ratepayers.

The English police and fire services, as disciplined and uniformed public services, permit comparative analysis of their working structures and the techniques engaged by their employers to manage them between the i $870 \mathrm{~s}$ and I930s. In particular, this article will focus on research conducted into police and fire brigade recruits, their responsibilities, the system of benefits awarded to each body, and the disciplinary codes enforced by employers to achieve loyal and complicit service. Rather than placing either service on a pedestal, this article posits that the experiences of English constables and firefighters offer a framework for international comparative research, and the final section will place the empirical research in an international context to tease out some of the main contrasts between the various models of policing and fire protection and, more importantly, their management.

Protection: In Pursuit of Municipal Networks in Edwardian Birmingham”, Urban History, 32 (2005), pp. $285-304$.

7. Clive Emsley and Mark Clapson, "Recruiting the English Policeman, c.1840-1940", Policing and Society, 4 (1994), pp. 269-285; Haia Shpayer-Makov, The Making of a Policeman: A Social History of a Labour Force in Metropolitan London, I 829-1914 (Aldershot, 2002); Terry Segars, "Working for London's Fire Brigade, I889-1939", in Andrew Saint (ed.), Politics and the People of London (London, 1989), pp. I67-185; Clive Emsley, "The Policeman as Worker: A Comparative Survey c.I800-1940", International Review of Social History, 45 (2000), pp. 89I ıо; Mark Clapson and Clive Emsley, "Street, Beat and Respectability: The Culture and SelfImage of the Late Victorian and Edwardian Urban Policeman", Criminal Justice History, I6 (2002), pp. 107-13 I; Mark Tebeau, Eating Smoke: Fire in Urban America, I800-1950 (London [etc.], 2003), ch. 6.

8. R.J. Morris, Class, Sect and Party: The Making of the British Middle Class (Manchester, 1990), p. $32 \mathrm{I}$. 
With improving access to transnational communications, public services plugged into a growing network of writings and visits that sought practical solutions to universal urban problems posed by crime, fire, and issues related to personnel management. ${ }^{9}$

The article will draw examples from two English cities, Birmingham and Leicester, which were representative of the experience of large and medium-sized cities respectively between the I 870 s and I930s. Both cities shared common characteristics as regional centres of manufacturing. Leicester was the centre of the footwear and hosiery industries in the East Midlands, while Birmingham led the West Midlands in the manufacture of jewellery and small metals. Moreover, both had enduring liberal political regimes dominated by small cliques of experienced politicians who played an active role in ordering civil society. Equally, both faced challenges throughout the period to their urban order, which legitimized the municipalization of police and fire services as tools of the local state to maintain public order and minimize risks. ${ }^{10}$

Care needs to be taken when comparing the police and fire services, however. For all their similarities in working cultures, "any idea that the fire brigade in Britain grew at a pace with, and alongside, the police is incorrect". Most importantly, there were few statutory controls governing firefighting. In fact, provincial municipalities were not even compelled to establish brigades before 1938 and many, in a process similarly evident in German towns, initially either devolved powers to fight fires to their police force or relied on insurance agencies or voluntary munificence to protect local communities. ${ }^{\text {I }}$

Leicester, for instance, was jointly protected by a police brigade and an insurance brigade between I 836 and I 872 whereupon they merged into a permanent, municipal brigade following complaints that the existing system of protection unfairly burdened insured property-owners. Birmingham, meanwhile, was protected by a privately-funded brigade until a police brigade was founded in I 874, which was replaced four years later by a professional brigade similar to Leicester's after a bungled attempt to rescue a family from a burning confectioners. ${ }^{\text {I2 }}$ Indeed, after I 865 London

9. Pierre-Yves Saunier, “Taking Up the Bet on Connections: A Municipal Contribution”, Contemporary European History, i I (2002), pp. 507-527.

I0. Further background to the socio-economic development of the case studies is available in E.P. Hennock, Fit and Proper Persons: Ideal and Reality in Nineteenth Century Urban Government (London, 1973); Bill Lancaster, Radicalism, Co-operation and Socialism: Leicester Working-Class Politics I860-1906 (Leicester, 1987).

I I. Police brigades consisted of constables appointed either wholly or partially on firefighting duties, and protected over 42 per cent of English and Welsh boroughs around I900: Shane Ewen, "Central Government and the Modernization of the British Fire Service, 1900-38", Twentieth Century British History, I4 (2003), p. 322.

I 2. Idem, "Power and Administration in Two Midland Cities, c. 1870-1938" (Ph.D., University of Leicester, 2003), pp. 17-20. 


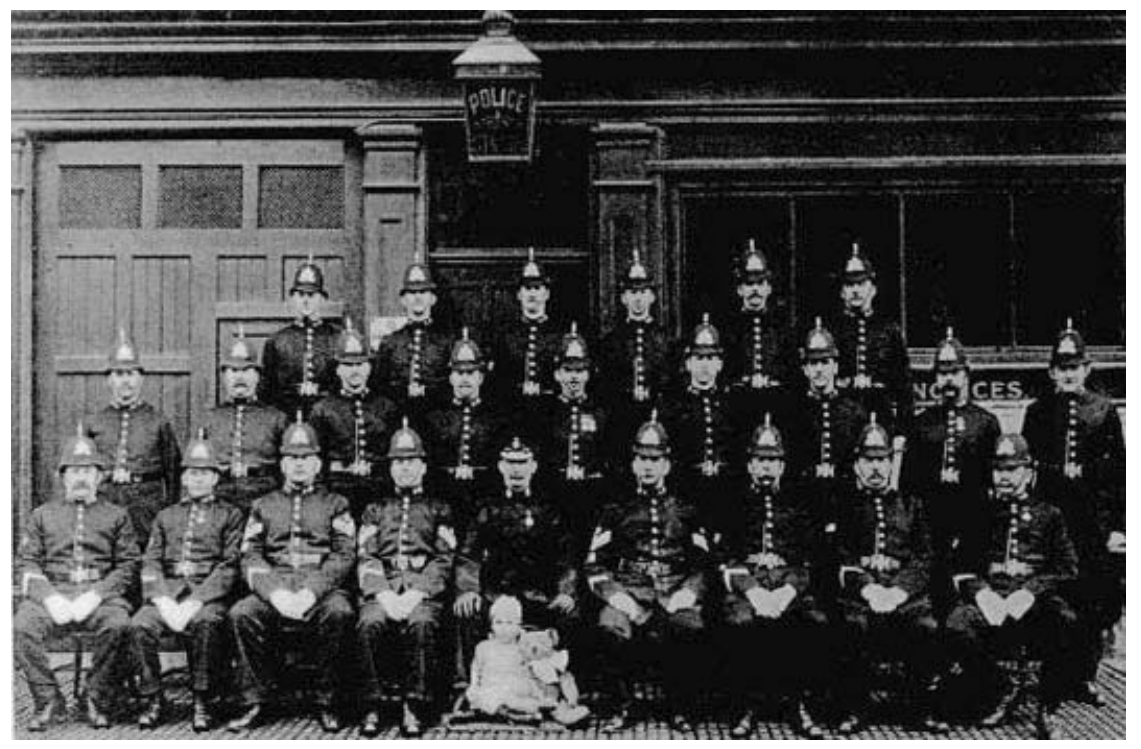

Figure I. Officers and men of the Leicester Borough Police Force, pictured outside the district police station in Queens Road, Clarendon Park, in I9 I I.

Source: Leicestershire Record Office, DE S49I/868/I3A

was England's sole state civilian fire brigade, and even then few continental brigades followed suit, with many, including the Dutch and Italian municipalities, relying on local or voluntary networks or, as in the case of Paris, establishing a state military service (the sapeurs-pompiers).

The police, meanwhile, was subject to increasing regulation from i 856 when legislation made the appointment of local forces mandatory. The system was coordinated by the inspectors of constabulary, on which an annual grant was contingent. With no exchequer funding or standards of efficiency in fire protection until World War II, the two services "developed a century apart". ${ }^{23}$ Yet despite their differences, constables and firefighters shared similar positions in working in uniformed and visible services, responsible for upholding public order, and subject to a disciplinary regime that conditioned their behaviour to adhere to austere controls imposed from above.

\section{RECRUITMENT TO THE POLICE AND FIRE SERVICES}

There were clear similarities between the strategies deployed by employers to recruit Victorian constables and firefighters. Most obviously, both were

I3. H. Parris, "The Home Office and the Provincial Police in England and Wales, I 856 -1970", Public Law (196I), pp. 230-255; Jonathan Powner, "Provincial Fire-Fighting in England I666I94I" (Ph.D., Keele University, I991), p. 33. 
increasingly recruited from the semiskilled classes. Police forces, the Metropolitan Police included, targeted working-class males, especially unskilled labourers who were deemed suitable for the physical rigours of beat patrol, for the greater part of the nineteenth century until improvements to material benefits, including sick pay, a guaranteed pension, and awards for meritorious behaviour, opened up the service as a long-term career for the lower middle classes by the turn of the century. This was especially true for the emerging "clerkocracy" which comprised poorlypaid office clerks, railway porters, and other transport officials. ${ }^{\text {I4 }}$ Fire brigades, meanwhile, recruited a combination of ex-sailors, well versed in the traditions of servitude and discipline, and tradesmen, who had the requisite knowledge of modern building construction and engineering. ${ }^{\text {Is }}$

Based on a random sample, from i 850 to I 899 Birmingham and Leicester police recruited 36.7 and 2 I.6 per cent of labourers respectively, whom they deemed to be hard-working and amenable to strict discipline (Table I). Leicester, however, appointed similar proportions of skilled industrial workers ( 23 per cent) and ex-soldiers (I6.3 per cent), which suggests that local characteristics, including the buoyancy of the economy and the proximity to military barracks, influenced recruitment patterns. Though it was not a requirement for a Victorian constable to have military experience, Leicester was certainly not exceptional in appointing exsoldiers, and recruited a further I9.4 per cent between I 900 and 1939. The police was an attractive career for ex-soldiers accustomed to the discipline of a hierarchical organization and served to reinforce the authoritarian structure and relationship of servility between the rank and file and senior officers. Although, however, English forces recruited ex-soldiers, they were not considered to constitute a "state military police" in the same way that the French gendarmerie or Italian carabinieri were. ${ }^{16}$ Moreover, with relatively high proportions of skilled industrial workers, including framework knitters, elastic weavers, and shoe manufacturers in Leicester and engravers, watchmakers, and glasscutters in Birmingham, policing offered job security with a guaranteed pension from 1890 and improved real wages by the I $920 s$. This was further reinforced by recruiting a steady proportion

I4. Emsley, "Policeman as Worker", p. 93; Haia Shpayer-Makov, "A Portrait of a Novice Constable in the London Metropolitan Police, c.1900", Criminal Justice History, I 2 (1991), pp. $142-148$.

I 5. Municipal fire brigades solely recruited men until women were appointed, albeit briefly, as watch-room attendants during World War II. A few voluntary brigades, including Girton College, the University of Cambridge, recruited women during the nineteenth century. Police forces recruited women on an ad hoc basis during the interwar years to undertake the service's increasing social welfare responsibilities. See Terry Segars, "War, Women and the FBU", in Victor Bailey (ed.), Forged in Fire: The History of the Fire Brigades Union (London, 1992), pp. I39-I 57; Louise Jackson, “'Lady Cops' and 'Decoy Doras': Gender, Surveillance and the Construction of Urban Knowledge, I919-1959", London Journal, 27 (2002), pp. 63-83.

16. Clive Emsley, Gendarmes and the State in Nineteenth Century Europe (Oxford, I999). 
Table I. Previous occupations of new police recruits (per cent) 1850-1939

\begin{tabular}{lccccc}
\hline Trade & \multicolumn{2}{c}{ Birmingham } & & \multicolumn{2}{c}{ Leicester } \\
\cline { 2 - 3 } \cline { 5 - 6 } & $1850-1899$ & $1900-1939$ & & $1850-1899$ & $1900-1939$ \\
\hline Labourers & 36.7 & 7.3 & & 21.6 & 4.4 \\
Skilled industrial & 16.1 & 18.3 & & 23.0 & 21.3 \\
Traditional trades & 9.8 & 7.1 & & 9.2 & 8.8 \\
Railway/transport & 6.5 & 12.0 & & 7.8 & 6.3 \\
Coal/metal trades & 6.5 & 7.9 & & 4.2 & 8.8 \\
Building & 6.7 & 6.3 & & 2.5 & 5.0 \\
Clerks & 4.4 & 16.3 & & 1.1 & 17.5 \\
Army & 2.9 & 5.5 & & 16.3 & 19.4 \\
Agricultural workers & 3.6 & 9.9 & & 4.2 & 3.8 \\
Constables in other & 3.6 & 1.8 & & 8.8 & 2.5 \\
forces & & & & 1.1 & 2.5 \\
Professionals & 2.3 & 6.4 & & 0.4 & 0.0 \\
Merchant seamen & 1.0 & 1.1 & & & 160 \\
Sample & 523 & 1,310 & & 282 & 250 \\
Average size of force & 514 & 1,222 & & 129 & \\
\hline
\end{tabular}

Source: West Midlands Police Museum (hereafter WMPM) I991.360-361, Birmingham Police Personnel Books, i863-1919; Birmingham City Archives (hereafter BCA) (unreferenced) Watch Committee Minutes (hereafter WC Mins), I917-I939; Leicestershire Record Office (hereafter LRO) $\mathrm{CM}_{42} / 8-33$, WC Mins, I 860-I 940; LRO DE $38_{31} / 323$, Nominal Roll of Leicester Police Officers, I888-I924; LRO $\mathrm{DE}_{3} 83 \mathrm{I} / 330$, Leicester Police Personnel Files.

from "traditional trades" (notably butchers, bakers, blacksmiths, and masons), building, and transport.

Contrary to Haia Shpayer-Makov's contention that police work "demanded no special skill or work experience", in recruiting from a diverse socio-economic base both forces consisted of constables with a variety of transferable skills. Those in the "traditional trades", for instance, were well-known in their community; those in transport had local geographical knowledge, while labourers were well versed in physical labour. Between 1900 and 1939 the numbers of labourers appointed declined in real terms and were replaced by white-collar clerks attracted by job security and promotion prospects. Recruitment of clerks increased appreciably from 4.4 to I6.3 per cent in Birmingham and from I.I to I7.5 per cent in Leicester. This shift was partly the consequence of an increasing burden of administrative work and, in return, demands for improved educational attainment. By attracting growing proportions of clerks to policing, then, both forces reinforced their commitment to recruiting groups that created a multi-varied skilled workforce.

Unlike policing, firefighting was in many cities socially exclusive. Before the late I930s the London Fire Brigade overwhelmingly recruited 
ex-sailors who it was felt could endure the long hours, harsh working conditions, quasi-military disciplinary regime, and the necessity of living over or around the station in tied housing. Some provincial brigades, Birmingham, Croydon, and Manchester included, followed this trend and excluded many tradesmen and labourers from their recruitment campaigns. Between I 880 and 1920 approximately one-half of all new firefighters appointed in Birmingham were recruited from the Royal Navy because its chief officers, Alfred Robert Tozer (I 879-1906), and his son of the same name (1906-I940), considered that the institutional controls and disciplinary procedures prevalent within the two services overlapped. ${ }^{17}$ The other half of Birmingham's recruits represented the skilled industrial and traditional trades' categories, including engineers, motor mechanics, bricklayers, and blacksmiths. By interacting with disciplined and motivated ex-sailors, such workers were expected to adapt their behaviour to their organizational environment and normalize their attitude towards discipline. Thus, Birmingham's firefighters, mirroring the experience of the French sapeurs-pompiers, quickly absorbed the quasi-military ideology of servitude.

Like the police, the diverse knowledge base of these recruits underpinned discourses of efficient service delivery, yet this was regulated by the recruitment of sailors who reinforced existing operational practices bounded by unwavering obedience to senior officers. Yet other brigades, epitomized by Leicester and Edinburgh, targeted semiskilled and skilled workers who utilized their skills in, for instance, building, roofing, and motor mechanics. Being trained engineers, Leicester's chief fire officers, William Ely (1889-1909) and Henry Neal (1909-1938), espoused the merits of utilizing practical skills for the benefit of local protection and to undertake the array of additional duties falling under the firefighter's remit, like maintenance work and building inspection. Thus, practical knowledge was, albeit in a few brigades, equally as important as unwavering discipline and courage, especially inasmuch as those with engineering experience were expected to channel their skills into fire prevention. ${ }^{\text {I }}$

\section{PAY AND PENSIONS}

Police and fire brigade work both offered regular pay and, from the late nineteenth century, a variety of long-term benefits. Before constables

17. Report of the [Middlebrook] Committee on the Hours, Pay, and Conditions of Service of Firemen in Professional Fire Brigades in Great Britain (hereafter Middlebrook), PP, 1920, vol. I6, pp. 38-43. The Tozer firefighting dynasty is discussed in Ewen, "Internationalization of Fire Protection", pp. 292-293.

18. Middlebrook, pp. 74-75. 


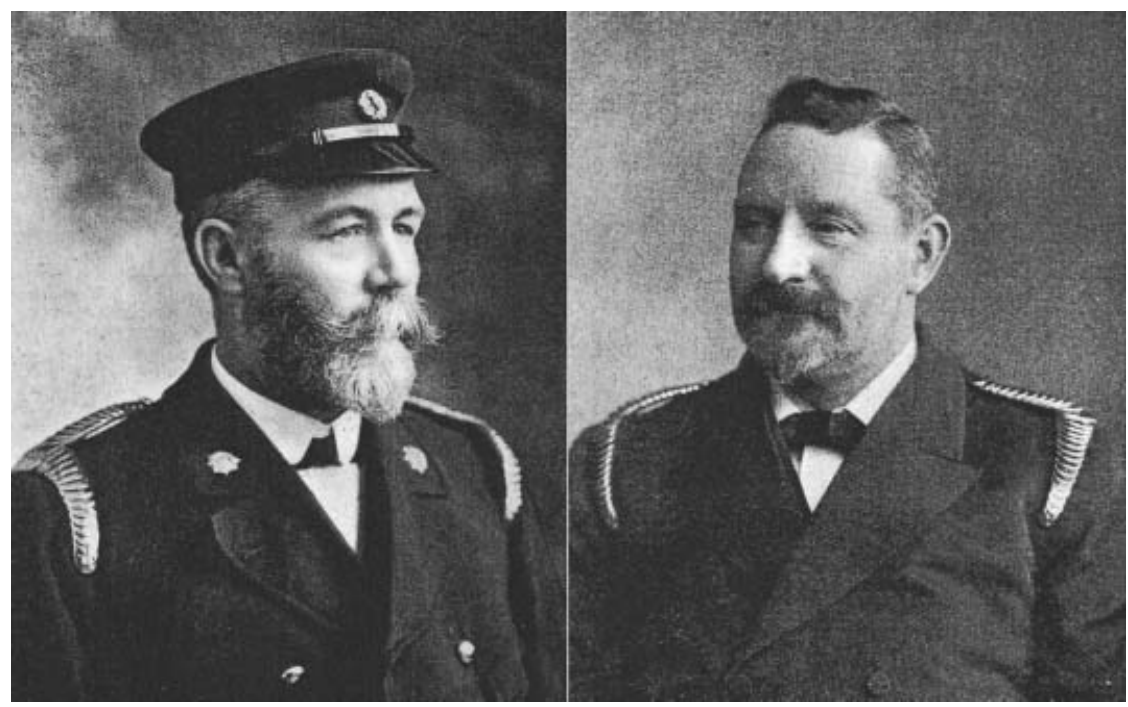

Figure 2. Left: Superintendent William Ely, Leicester Fire Brigade (1889-1909), formerly superintendent and engineer Chester Fire Brigade (I883-I889); right: Alfred Robert Tozer, first chief officer of Birmingham Fire Brigade (1879-1906), formerly chief superintendent of Bristol Police Fire Brigade (I877-I879).

Source: Fire \& Water, June 1906, p. s2; September 1906, p. 99

finally received guaranteed pensions from i 890 , however, there was widespread unrest that the arbitrary system in place, coupled with low wages, which were not on a par with those of other respectable workingclass trades, contributed to high labour turnover. ${ }^{19}$ Yet by the I900s the police profession had evolved into an attractive career through the provision of pension rights, sick pay, and rent allowances. This undoubtedly alleviated the Edwardian constable's grumble at declining real wages, which undermined the financial appeal of policing as a vocation comparable to skilled trades like printing and engineering (Table 2 overleaf). This unrest intensified before police pay was substantially increased and standardized in I91 8 following strike action in a few forces, Birmingham included. Indeed, by the mid-I920s when police pay remained statutorily fixed, moves to freeze wage increases to augment economy in public services and return constables to an earlier wage parity, did not prevent the police profession in Birmingham and Leicester continuing to offer a lucrative career trajectory to those willing to offset this for an arduous working life. ${ }^{20}$

19. David Taylor, "The Standard of Living of Career Policemen in Victorian England: The Evidence of a Provincial Borough Force", Criminal Justice History, I 2 (1991), pp. I07-1 3 I. 20. Emsley, English Police, pp. I30-136. 
Table 2. Real wages in Birmingham and Leicester (average weekly earnings $), 1905-1926(1914=100)$

\begin{tabular}{|c|c|c|c|c|c|c|}
\hline \multirow[t]{2}{*}{ Occupation } & \multicolumn{2}{|c|}{$1905(92)$} & \multicolumn{2}{|c|}{$1914(100)$} & \multicolumn{2}{|c|}{$1926(170)$} \\
\hline & B'ham & Leic. & B'ham & Leic. & B'ham & Leic. \\
\hline Police constable & 98.7 & 98.7 & 91.9 & 86.5 & 95.4 & 95.4 \\
\hline Firefighter & 85.1 & 88.5 & 79.7 & 87.8 & 95.4 & 95.4 \\
\hline Engineering labourer & 68.1 & 68.1 & 59.4 & 54.0 & 46.3 & 46.8 \\
\hline Fitter and turner & 122.6 & 115.8 & 102.7 & 100.0 & 64.7 & 63.6 \\
\hline Iron moulder & 129.4 & 129.4 & 108.1 & 102.7 & 67.1 & 64.7 \\
\hline Printing compositor & 117.5 & 114.1 & 101.3 & 97.3 & 86.1 & 82.7 \\
\hline Boot and shoe clicker & - & 98.7 & - & 81.1 & - & 61.9 \\
\hline Framework knitter & - & 98.7 & - & 87.8 & - & 61.9 \\
\hline
\end{tabular}

Source: Report of an Enquiry by the Board of Trade into Working-Class Rents and Retail Prices, PP, I9I3, vol. 66; Abstract of the Ministry of Labour Statistics for the United Kingdom, PP, I926, vol. 29, p. 29.

Perceptions of a fire profession offering security and job satisfaction were much slower to emerge. Not only did a firefighter's pay lag behind that of a constable in both cities until I9I8 (wherein the threat of strike action caused employers to establish parity), but he did not have access to a similar incentive culture. The biggest difference between the two concerned the right to a guaranteed pension. Following inquiries into the funding of police retirement, constables were granted in I 890 the right to retire after twenty-five years' service on two-thirds pay. Such generous provision, which exceeded that provided to other public service workers, including teachers and postal workers, stabilized the service's structure whilst legitimizing its disciplinary regime. If constables were prepared to obey the rules governing their behaviour then it was deemed proper to reward their loyalty. By guaranteeing their standard of living until death it also avoided the embarrassment of forcing retired constables to apply for poor relief. The main concessions granted to disgruntled local employers, the provision of an annual grant and the inclusion of the contributory principle, meant that local costs were minimized and that the constable would himself value individual thrift.

Despite protestations that their work was equally important, negotiations over the award of a pension for firefighters dragged on for three and a half decades before legislation was finally enacted after local authorities had secured the principle of contribution. This ultimately meant that in the interim a polarized system of benefits emerged, which weakened the development of a collective identity. For example, from i 893 members of police brigades were legally entitled to the police pension. A few progressive brigades, including Birmingham and Leicester, established separate funds for their firefighters between I 890 and I9I0, yet on a lower 


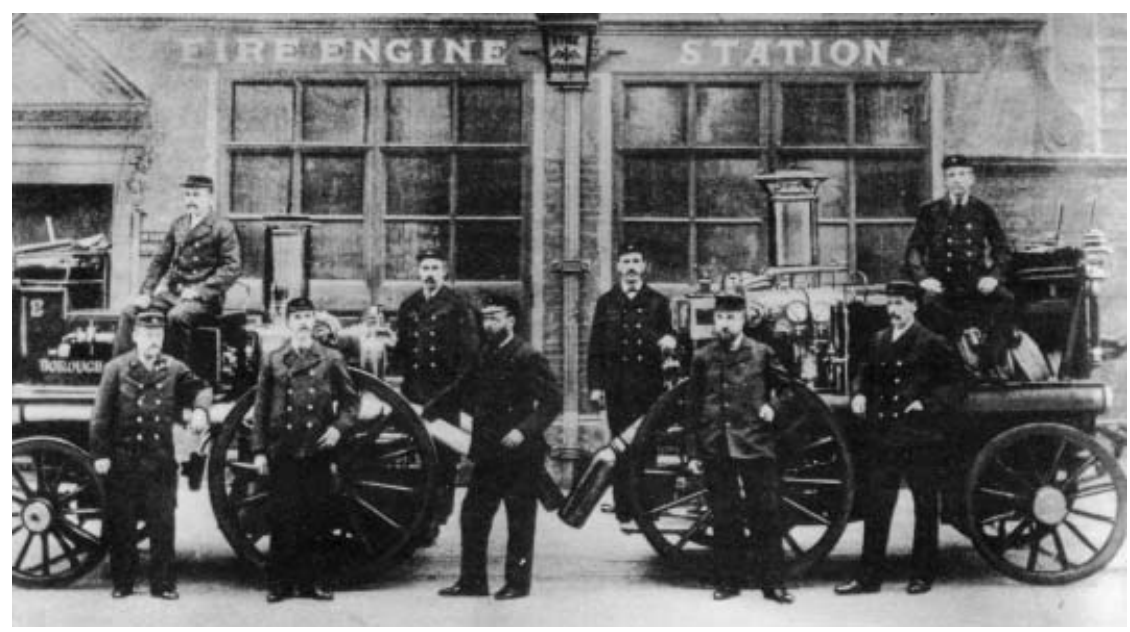

Figure 3. Members of the Leicester Fire Brigade with two horse-drawn steam fire engines outside the central station in Bowling Green Street, I 892. Superintendent Ely is pictured (third from left in front row).

Source: Anonymous, Leicester's Battle Against Fire (Leicester, I892), p. I 8.

scale than the police. The majority of brigades, however, either refused to provide for their firefighters' long-term security or granted pensions arbitrarily. The eventual award of a pension in 1925 for those working in professional brigades adopted elements of the police scheme, yet was locally funded. Legislation was less the recognition that pensions were considered a right for the hard-working firefighter than a trade-off between employers and the rank and file to accept the reactionary disciplinary code prevalent in the service.

The underlying reason for this disparity between the two services originated in how each was managed and reflected competing perceptions. As a "local" responsibility, it was of qualified interest to policy-makers whether labour turnover in the fire service was a problem or not. Firefighting was derided as an unskilled occupation and the demand for labour was easily met by an increasingly mobile population. ${ }^{21}$ For example, Arthur Dixon, under-secretary of state at the Home Office, noted the difficulties posed by "the exclusively local character of the service" in response to lobbying by the Professional Fire Brigades Association, the nascent profession's mouthpiece, in 1920 for the introduction of a pension scheme. Dixon also doubted claims that the

2I. For example, in 1909 there were 109 applications for 6 positions in Leicester Fire Brigade: Leicestershire Record Office (hereafter LRO) $\mathrm{CM}_{42 / 22}$ Leicester Fire Brigade Sub-Committee Minutes, 7 October 1909, pp. 224-225. 
firefighter's role was as arduous as that of the constable. Whilst the latter was exposed to a multitude of dangers and weather conditions on his daily eight-hour beat, the former "spends a very considerable portion of his time in the shelter and warmth of a station". Moreover, the constable was expected to command an extensive working knowledge of his occupation and was burdened with a "much greater" responsibility in using his discretion. Despite his failure to recognize the dangers and technical demands associated with firefighting, Dixon's perception of the service as an unskilled occupation was not an exceptional misconception. ${ }^{22}$

Notwithstanding these critical differences, the offer of regular pay, the provision of free or subsidized accommodation, the availability of awards for meritorious behaviour, the attraction of a free uniform, and the creation of a common subculture contributed to a shared working experience between the constable and professional firefighter. ${ }^{23}$ In addition, devotion to service equally impacted on a worker's family. Police wives, for example, were forbidden from undertaking certain jobs, notably in the drinks trade, and often performed unpaid secretarial work for their husbands. ${ }^{24}$ A firefighter's family, meanwhile, was forced to live near to the fire station, where they were subject to the same disciplinary regulations. Their sons, born and raised in the service, followed their fathers in the brigade where they benefited from accelerated promotion. Prominent firefighting families, including the Tozers of Birmingham and the Johnsons of Southampton, dominated the higher echelons of their organization, their brigades becoming the mafiosa of single families. ${ }^{25}$ Clearly, then, there were advantages to joining the service, although this was not always played out fairly for all workers.

\section{DUTIES AND RESPONSIBILITIES}

The late Victorian urban constable was "seen everywhere and at all hours carrying out his duties". ${ }^{26}$ Power clearly pervaded the Victorian and Edwardian police because policing and the control of urban space were interlocking strategies. City spaces were thus divided into police districts,

\footnotetext{
22. Middlebrook, p. I29.

23. For example, Haia Shpayer-Makov, "Relinking Work and Leisure in Late Victorian and Edwardian England: The Case of a Police Subculture", International Review of Social History, 47 (2002), pp. 2I3-24I.

24. Barbara Weinberger, "A Policewife's Life is Not a Happy One: Police Wives in the I93os and I940s”, Oral History, 2 I (1993), pp. 46-53.

25. I.T. Johnson (I884-I90I) and his son (I90I-I9I 8) were both chief officers of Southampton Fire Brigade, while the latter's five brothers also served in the local brigade and were later appointed high-ranking officers in the London, West Ham, Gloucester, and Ramsgate brigades; A. House, Gateway Fire-Fighters: A History of the Southampton Fire Brigade (Southampton, 1996), pp. 44-45; Ewen, "Internationalization of Fire Protection", p. 292.

26. Shpayer-Makov, "Portrait of a Novice Constable", p. I33.
} 
Table 3. Allocation of police beats, 1911-1920

\begin{tabular}{lcc}
\hline & Number of day beats & Number of night beats \\
\hline Birmingham, 1920 & 218 & 365 \\
Leicester, 1911 & 20 & 42 \\
\hline
\end{tabular}

Source: BCA (unreferenced) Judicial Sub-Committee Minutes, I6 November I920; LRO DE549I/307, Major J. Hall-Dalwood, Bye-Laws, Rules and Regulations of the Borough of Leicester Compiled for the Use of the Police (Leicester, I9I I), p. I46.

and further subdivided into beats, "the cornerstone" of urban policing between the I870s and I930s, which were patrolled by one or two constables on day and night duty to deter crime. ${ }^{27}$ Moreover, by regulating policing both temporally and spatially, manpower could be deployed according to risks. This was particularly evident in Birmingham and Leicester where night beats were far more prominent to allow the police to provide additional protection to commercial properties outside working hours (Table 3).

Both forces, for example, organized schemes from the i 870 s for local businesses to deposit spare keys to their premises to facilitate easy access in case of burglary or fire at night. A constable was expected to meticulously supervise commercial properties at night and was "in a great measure responsible for the safety of all property [...] in the district which he is detailed to patrol". Chief constables from both forces also recorded the number of unsecured premises in their reports to underline the importance of vigilant night patrol. ${ }^{28}$ Aside from supplying an additional revenue stream for both forces, this strategy reinforced the entrepreneurial spirit of policing, and the consensual and interactive relationship between the police and local ratepayers.

If constables were expected to be seen everywhere at all times, firefighters had the potential to be permanently visible and performing a multitude of duties. Contrary to traditional stereotypes, firefighters did not simply perform a reactive firefighting role, with employees in Birmingham and Leicester engaged in a preventative capacity from the I900s, including the inspection of licensed theatres under public health legislation and vetting of building plans to ensure that adequate exits were installed. Constables were concurrently involved in far more than crime detection. Preventative policing accounted for the lion's share of police

27. Brogden, On the Mersey Beat, p. 36. This was a common practice in western Europe, with two-man patrols popular in France and Spain.

28. LRO DE 549I/307, Major J. Hall-Dalwood, Byelaws, Rules and Regulations of the Borough of Leicester Compiled for the Use of the Police (Leicester, I9I I), pp. I54-I55; West Midlands Police Museum (hereafter WMPM) 1991.24, Borough of Birmingham, General Regulations for the Government and Guidance of the Police Force (Birmingham, I878), pp. I2-14. 
work in Birmingham and Leicester, as well as continental forces, despite growing interest in detection, especially across national boundaries. ${ }^{29} \mathrm{On}$ the one hand, regulation involved the policing of social behaviour in the ubiquitous "moving on" "ritual", but also through individual activities such as the supervision of public houses, brothels, and gambling dens.

For example, an investigation by the Birmingham Post found that in I 909 the police conducted 34,92 I inspections of licensed premises, I,760 inspections of theatres and music halls, removed 3,703 stray dogs from the streets, returned I, 545 lost children to their parents, reported on 4,829 insecure premises, licensed $97 \mathrm{I}$ premises for the storage of explosives, and deposited 5,I47 items in the lost-property office. ${ }^{30}$ On the other hand, regulation also involved the physical control of the streets, which included policing traffic on the increasingly teeming thoroughfares. Between I93 I and 1933, for instance, Leicester's constables covered an average of 742.7 miles each on traffic-related duties brought about by rising congestion, spending up to 22 per cent of their working lives on traffic patrol. ${ }^{\mathrm{I}}$

The practice of beat policing enabled constables to access operational resources, albeit within narrow constraints. For example, a policy change within Leicester Police in November 1907 saw its chief constable grant constables "greater freedom" in patrolling their beat flexibly to prosecute public order offences. That all constables had to prearrange their movements with sergeants so that they could determine supervision by the patrol inspectors indicates that this negotiated autonomy remained bounded and that the beat provided senior officers with "an insidious device of control and discipline" over the constable. ${ }^{32}$ Concurrently, according to Cecil Moriarty, Birmingham's assistant chief constable (1918-1935) and the author of several prominent handbooks on police law and administration, constables were expected to have an extensive working knowledge of criminal law and an understanding of the local characteristics of its interpretation. ${ }^{33}$

Thus, constables and firefighters were jointly responsible for service delivery, a multi-faceted process that demanded substantial professional knowledge. Unlike firefighters, however, constables had scope for operational decision-making within a narrow framework of autonomy.

29. For example, Mathieu Deflem, Policing World Society: Historical Foundations of International Police Cooperation (Oxford, 2002), chs I-2.

30. Birmingham Post, 2 July 19 ro.

3I. These figures are calculated from road patrol work, patrol work under the police box system, travelling to emergency calls, and conveying prisoners to and from prison: LRO DE 549 I/260267, Leicester City Police Annual Reports, 1930-1937.

32. LRO DE 38 1 I268, Leicester City Police Chief Constable's Special Order Book, I9 November 1907; Brogden, On the Mersey Beat, p. 36.

33. Cecil Moriarty, "The Making of an English Policeman”, Police Journal, I 2 (1929), pp. 5-6; idem, Police Law (London, I929); idem, Police Procedure and Administration (London, 1930). 
The skills, resources, and attitudes of the police influenced operational decision-making, yet such decisions overlapped with wider policy questions and were embroiled within a process of surveillance and selective recruitment.

\section{DISCIPLINING THE DISCIPLINERS}

The positions of constable and firefighter equally demanded discipline and were subject to the vagaries of a hierarchical organizational structure. The mid-nineteenth century heralded a "transition to order", which instilled characteristics of obedience and self-discipline into the lower ranks of public-sector organizations. ${ }^{34}$ Constables and firefighters were accorded no supervisory status, but were themselves liable to intensive surveillance from senior officers. In return for their self-discipline, Shpayer-Makov has suggested that the police was organized according to a "new paternalism" that combined bureaucratic procedures governing a constable's operational autonomy with controlled welfare provision. Based on "vertical relations" between employer and employee, this "new paternalism" reinforced the practice of polyvalent power relations within the police. ${ }^{35}$

The threat of disciplinary action was an underlying feature of the strategies engaged by senior officers and employers to manage the police and countered suggestions that police work was increasingly governed by the doctrine of constabulary independence. A constable's legal autonomy was constrained by rules installed by the collaborative powers of the chief constable and watch committee, through which they demanded loyalty, obedience, and fitness. If the beat was "the cornerstone" of police practice, discipline was the pivot of police "governance," affecting the everyday routines of the rank and file, and causing consternation amongst the inspectors of constabulary at the legal responsibilities vested in watch committees. ${ }^{36}$

Yet in Birmingham and Leicester, the watch committees had deliberately withdrawn from dealing with personnel matters by the igros and had delegated substantial authority to their chief constables. They were uninterested in the idiosyncrasies of daily policing beyond ratifying the chief constable's punishments. Constables were usually only called before the committee in groups and their first visit was to swear an oath of allegiance to the municipality. In effect, impersonality reinforced civic authority. Unlike in small towns, both watch committees' members rarely interacted with the rank and file on a social or professional basis. Unless a constable had performed an act deserving a meritorious award, challenged

34. Patrick Joyce, Work, Society and Politics (Brighton, I980), p. 94.

35. Shpayer-Makov, Making of a Policeman, pp. I 53-1 56.

36. H.M. Inspectors of Constabulary Annual Report 19I8-19, PP I920, vol. 22, p. 5. 
a punishment authorized by the chief constable, or committed an offence of such gravity that it threatened to undermine the force's reputation, he could spend the majority of his career without interacting with the watch committee beyond attending ceremonial functions, such as the Birmingham Police Band's civic concerts during the late I920s. ${ }^{37}$

"Drinking on duty" was the most frequently recorded offence within police ranks between the I870s and I930s, and was the main reason cited for dismissal in both forces. ${ }^{38}$ Councillors and senior officers bemoaned the inability of constables to resist the temptation of drinking alcohol in dark alleyways or public houses on their beats. Both forces took steps to eradicate intemperance, passing resolutions threatening strict punishment and revoking the licenses of publicans caught serving constables. ${ }^{39}$ Yet the proportionate decline of drink-related offences from 28. I and 39.3 per cent in Birmingham and Leicester respectively between I 890 and I9I9 to 17.3 and 8.0 per cent each during the interwar years was less the consequence of increased temperance and more a result of real increases in other offences, notably "neglect" and insubordination. The former was interlinked with drunkenness in that it influenced inattention to duty, yet both forces adopted arbitrary definitions of "neglect" and used it for any offence not neatly categorized, including failure to implement orders, allowing suspects to escape, and improperly patrolling the beat. ${ }^{40}$

Insubordination was a persistent problem from the I 890 , particularly in Birmingham where it regularly exceeded 20 per cent of all offences. ${ }^{4}$ This long-term consistency led senior officers to bemoan the lack of respect from constables, blaming the influence of unionization and the spread of social welfare within the service for such attitudes. In return, constables complained that particular officers singled them out for unfair treatment. Inspectors Choyce and Carson, for example, regularly criticized the attitude of one Leicester constable, claiming that he was unreliable, rude, and "absolutely worthless as a police officer", yet Inspectors Clarke and Faulkner found the same individual "most attentive, zealous and efficient in the performance of

37. Shane Ewen, "Civic Identity and Police Leisure in Birmingham during the Inter-War Years”, International Journal of Regional and Local Studies, series 2, I (2005), pp. 44-62.

38. This section is based on quantitative analysis of 1,936 recorded offences for the Birmingham Police and 565 offences for the Leicester Police between I 860 and 1939. The data was sampled from WMPM i991.360-36r, Birmingham Police Personnel Record Books; WMPM 1991.350, Birmingham Police Defaulters' Book; LRO CM42/9-32, WC Mins.

39. For example, LRO DE 383 I/266, Leicester City Police Special Orders, 9 April I 894, p. I 25. 40. This broad definition of "neglect" was reflected in the proportion of such offences rising from I 2.8 and 9.8 per cent in Birmingham and Leicester respectively during the I 870 s to 34.9 and 34.7 per cent each during the I930s.

4I. In Leicester insubordination fluctuated between 5.9 per cent during the 1900 s to 36.7 per cent during the I920s. 
his duties". ${ }^{2}$ The influence of agency within internal organizational and disciplinary relations could, then, weaken rational structural regulations. Thus, human input into internal power relations had farreaching consequences for the access of individual constables to benefits.

Lack of punctuality was also becoming a problem in Birmingham Police, accounting for 34.6 per cent of "other" offences between 1920 and 1929 and indicating that the continued expansion of the city, especially after the creation of Greater Birmingham in I9I I trebled the city's acreage, and the growth in traffic congestion adversely affected timekeeping. From 1900 any constable more than one minute late for duty in Leicester was fined one day's pay. Persistent latecomers were forced to resign. ${ }^{43}$ The majority of these offences could be addressed internally without resorting to external judgement, which suited the watch committee and chief constable.

Constables were given the opportunity to explain their actions for most misdemeanours and often obtained the benefit of the doubt from senior officers, although this was more often the case in Birmingham where I 4.6 per cent of offences between I860 and I939 were found to be either "explained" or "not proven", compared to 3.6 per cent of such cases in Leicester. Both forces used verbal punishments, cautioning or reprimanding constables for minor offences. The watch committee chairman invariably reprimanded those constables brought to his attention, reinforcing his social superiority in the process. The recording of admonishments in the committee's minute book suggests that the disciplining of constables by social elites was an important tool for demonstrating the accountability of the police to the municipality amid claims that the constable was operationally independent. ${ }^{44}$

Dismissal was a constant threat in both forces though used infrequently in Birmingham until the I 890 s due to concerns over labour turnover, whereupon it accounted for almost a fifth of all punishments, compared to almost a third in Leicester. Within this category, both forces overwhelmingly preferred "asking" constables to resign, although it was more of an obligation than a request. Dismissal was a last resort, the culmination of a number of offences, or the consequence of a major breach of discipline like theft or violence, especially when involving members of the public. 45 Financial punishments, meanwhile, which included pay cuts, a reduction in rank and fines of an average of one day's pay, were prevalent in both

42. LRO DE 549I/337, Leicester City Police Personal Records, 29 December I9I 5, I 2 February 1917.

43. For example, LRO CM42/i9, Watch Committee Minutes (hereafter WC Mins), i6 October I900, p. 227.

44. For example, LRO CM42/20, WC Mins, 2 December I902, p. 78; LRO CM42/30, WC Mins, Is May 1934, p. 248.

45. For example, WMPM 1991.360, Birmingham City Police Personnel Books, 23 March i89i. 
forces, accounting for over one-half of all punishments in both forces during the I860s, I870s, I 920 s and I930s, and almost one-half during the other decades. Both watch committees devolved authority for imposing small fines to their chief constable from the I900s, which virtually absolved them of responsibility for minor fines.

If discipline was one of the underlying influences within police management, it was the driving force behind the management of fire brigades. Even as late as the I920s senior officers considered that an effective disciplinary regime should encapsulate "obedience, responsibility, restraint, control, self-effacement, and even sacrifice in the individual, and good order, rule, and well directed effort in the collective body". ${ }^{6}$ As most professional firefighters worked the continuous duty system, whereby they were available for call at all times of the day and night, employers insisted that it was their right to control a firefighter's public and private life. A firefighter, then, was always at work and, consequently, subject to intrusive regulation.

To the uninitiated, the service's disciplinary regime appeared ruthless. Consisting of a combination of monetary and non-material punishments, firefighters were disciplined for minor misdemeanours from their appointment to drill the importance of obedience and individual sacrifice into them. Indeed firefighters were the products of a suffocating collective environment that constrained their individuality, and any attempt to challenge the authority of senior officers was brutally quashed. Ultimately this quasi-military regime meant that insubordination was rarely a problem within local brigades. The most prominent misdemeanour, lack of punctuality, accounted for 42.8 per cent of all offences in Birmingham Fire Brigade between I 880 and I 939.47 By emphasizing the importance of punctuality when responding to emergency calls, senior officers operated an elaborate system of reprimands, fines, and additional duty for latecomers, especially those caught "missing the machine". ${ }^{8}$ Both Birmingham and Leicester set high standards for responding to fire alarms, regularly testing the response rates of their engines and employees, and altering the environment in which firefighters lived and worked

\footnotetext{
46. Fire, December 1923, p. I 52.

47. This section is based on quantitative analysis of $\mathrm{I}, 034$ recorded offences for the Birmingham Fire Brigade sampled from Birmingham City Archives (hereafter BCA), MS I $_{3} 0_{3} / 76$, Birmingham Fire Brigade Defaulters' Book. This includes 56 offences for I 880-1 889, I0 I for I $890-$ I 899 , 203 for $1900-1909,200$ for $1910-1919,236$ for $1920-1929$, and 238 for 1930-1939. Comparative data was unavailable for Leicester Fire Brigade.

48. "Missing the machine" refers to firefighters who failed to attend a call with the fire engine. Cautions or reprimands were the most frequent punishment given to firefighters, accounting for an average of 49.5 per cent of all punishments between i 880 and 1939, with cancelled leave following at a decennial average of 19.6 per cent. Financial punishments only accounted for an average of 2.4 per cent, and were in real decline throughout the period, accounting for only 0.4 per cent from 1920-1929 and none at all from 1930-1939.
} 
through the installation of sliding poles and electric bells, the result of international circulations of technological innovations from their north American and German origins, to maximize turn-out times. ${ }^{49}$

The majority of disciplinary offences in both brigades were dealt with internally, with Birmingham's chief officer handling over 90 per cent of all recorded cases between I 880 and I939. This meant that firefighters were given the opportunity to defend themselves against accusations and, by implication, 2I.3 per cent of all reported offences between I 880 and I939 in Birmingham were found to be either satisfactorily "explained" by the offender or deemed "unproven". Firefighters were reported for committing similar offences as constables, albeit with different emphases. "Drinking on duty", for example, was never a major concern for Birmingham and accounted for a declining proportion of offences between I 880 and 1929. To deter others, however, the chief officer made public examples of those caught incapacitated through drink by forcing them to do unpopular duties usually reserved for probationers like cleaning toilets or washing the station floors. . $^{\circ}$ Meanwhile, like the police, "neglect" accounted for a growing proportion and variety of offences, peaking at 65.5 per cent during the I930s.

Indeed, Birmingham Fire Brigade's disciplinary regulations were representative of provincial authorities' attitudes towards subservience. From its formation in 1879 the brigade maintained detailed ledgers wherein the record of each firefighter was recorded. Details of all misdemeanours were recorded along with their punishment. Alongside this were also recorded details of meritorious behaviour which included, upon their inception in 1920 , the award of good conduct chevrons which brought incremental pay rises and improved promotion prospects. As with the police, then, the threat of punishment within professional fire brigades was counterbalanced by an elaborate system of rewards that created a potent organizational resource utilized to maintain operational control.

Although attitudes towards the recruitment of firefighters differed between the two brigades, the characteristics of discipline, obedience, and comradeship linked both together. Regardless of their previous employment, firefighters were expected from the igoos to be knowledgeable about building construction and aware of the dangers posed by chemicals and electricity. Thus employers demanded a similar inclination from firefighters to learn a range of technical skills as for constables to interpret the law. The balance between knowledge and discipline influenced the maintenance of unequal power relationships between the rank and file and senior officers, with the former having access to a range of informational

49. For example, Fire \& Water, April 1904, p. 27.

50. For example, BCA MS I 303/4I, Birmingham Fire Brigade General Orders, 27 March I889, p. I4. 
resources, not least the skills inherited from previous occupations and their labour power, whilst the organizational characteristics of both services constrained their autonomy and reinforced their subservience to dominant structures of authority.

\section{INTERNATIONAL PERSPECTIVES}

The persistence of the municipal structure of police and fire services in English provincial cities serves as a benchmark against which comparisons can be drawn with other Western models to examine the strategies engaged to manage uniformed public services. Evidently, the English model was not ubiquitous in its adoption both on the European continent and further overseas. Methods of managing services depended on the structures of authority and legal traditions developed over time and the circulation of knowledge by interested individuals through transnational networks. Moreover, the cultural values ascribed to municipal government and the professionalizing influences over blue-collar public services determined attitudes towards the extent of local autonomy and authority. ${ }^{5 \mathrm{I}}$

Taking fire services first, if the English model was characterized by piecemeal professionalization within a broader framework of quasimilitary disciplinary control, some of the continental models, especially that of the French sapeurs-pompiers, were characterized by an overbearing military ethic of service in the name of national security. Not dissimilar to Fouche's gendarmerie, the French fire service was more than a purely firefighting force. On his visit to Europe during the ig0os, the chief officer of the New York Fire Department, John Kenlon, noted with awe that the Parisian firefighter could be called upon for military duty. Likening firefighting to a military battle, Kenlon accepted that both functions demanded the "unquestioning obedience of all ranks to their superior officers". This commitment to discipline was evident to Kenlon who, despite being a product of the American municipal system, recognized that "when fighting as crafty an enemy as fire, it requires not only the skill of the commander but also confidence and prompt compliance with orders on the part of subordinates". $5^{2}$ Conditions of service and attitudes towards internal discipline were conditioned by the view that the Parisian service was a "corps d'élite", with firefighters recruited from the ordinary infantry regiments and pay aligned with that of the army. The firefighting corps adopted the army's ranking structure and nomenclature, while firefighters

5I. As might be expected, the experience of firefighters and police constables in capital cities was slightly different from that of the provinces, as the organization of fire brigades and police forces in London, Paris, Berlin, amongst others, was more centralized. However, as this section draws heavily on contemporary publications, which focused overwhelmingly on capital cities, some examples will be referred to as a point of comparison with English provincial cities.

52. John Kenlon, Fires and Fire-Fighters (London, 1914), pp. 45-49. 
were domiciled in army-style barracks and managed under military discipline. A Manuel du Sapeur Pompier, published by the Ministry of War, was issued to all recruits through which the ideals of military service and obedience were propagated.53

In the provinces, though, fire services were invariably formed as sections of the French civic guard under the management of communal government. However, this strict military ethos pervaded the service nationally following moves in 1903 to enlist men in ex-officio military ranks, enforce a minimum service of five years, and direct brigades to assist the military in containing serious accidents and national emergencies, which involved the arming of some firefighters. Such an "esprit de corps" was preceded with the formation in 1900 of the International Federation of Fire Brigades, through which the French exported its model of firefighting to an international audience. Although the exercise was ultimately unsuccessful beyond its adoption in neighbouring Belgium, Switzerland, Luxembourg, and the French colonies, the Federation's central role in the dissemination of information on firefighting and the internationalization of fire prevention contributed to the emerging "urban internationale", which was crystallized in I9I 3 with the formation of the Union Internationale des Villes (UIV/IULA). 54

Although brigades like Birmingham and Leicester visited French and Belgian cities during the I900s to inspect their organizational methods, they were generally more impressed with the efficiency of the German municipal brigades, many of whom had become the progenitors of service reform by the late nineteenth century. With their traditions of civic government, cities like Hanover, Hamburg, and Munich adopted new technologies in steam traction and street alarms far earlier than their English counterparts, and organized paid blue-collar corps in response to local disasters such as Hamburg's "Great Fire" of I 842. Even Berlin, subject to Prussian centralized control, maintained an internationally respected police brigade by the mid-i 850s, which shamed the English brigades by merging powers of firefighting, building construction, and factory inspection from the 1870 s. Moreover, in the management of its firefighters, the Berlin authorities solely recruited from the military or technical professions. Promotion to officer class was contingent on passing a challenging examination in architecture or civil engineering at a royal technical college, leading Kenlon to praise the brigade as "the height of scientific efficiency".55

53. Charles Young, Fires, Fire Engines, and Fire Brigades (London, I866), pp. 475-477.

54. Pierre-Yves Saunier and Renaud Payre, "Municipalités de tous pays, unissez vous! L’Union Internationale des Villes ou l'internationale municipale (I9I3-1940)", Amministrare, 30 (2000), pp. $217-239$.

55. The Fireman, I (1888), pp. 21 I-212; Young, Fires, Fire Engines, and Fire Brigades, pp. 478-80; Kenlon, Fires and Fire-Fighters, pp. 64-74. 
The purpose of Kenlon's visit to Europe had been to encourage the sharing of expertise on universal urban problems associated with fire. In turn, by promoting the internationalization of fire prevention, Kenlon reflected the north American experience of firefighting, especially in its transition from a voluntary to a municipal, paid system. Indeed, north American brigades suffered from acute ill-discipline as early as the I $840 \mathrm{~s}$ and I 850 s, with voluntary firefighters criticized for drunken, lewd, and violent behaviour characterized by the populist representations of "Mose the Bowery B'hoy". ${ }^{6}$ The transition to a professional service, then, was a prevailing strategy in the disciplining of public service workers and the regulation of urban spaces under threat from fire disasters through the rapid growth of combustible cities like Chicago, Boston, and San Francisco. 57 Through a network of transnational visits and writings, progressive actors like Kenlon sought to popularize preventative measures in building construction, inspection, and fire-fighting. The management of uniformed firefighters was one aspect of this broader preventive strategy through which individuals like Kenlon, Edwin O. Sachs, the German-born architect and fire engineer, and Charles Young, the English engineer, shared best practice and contributed to the standardization of firefighting technologies.

This diversity in experience of managing fire brigades was similarly evident in the police service, although some of the ideas that informed the function of this uniformed service differed markedly. Two years after his visit to Europe in I9I 3, which had been commissioned by the Rockefeller Foundation, Raymond Fosdick, the American city bureaucrat, published the first transnational study of police administration. Informed by a selfcritical view of American city policing, not least in the pervasive influence of patronage politics, and an enduring fascination amongst American social reformers in western European public services, Fosdick praised European police forces as enjoying "an excellent reputation" that was generally resistant to corruption and scandal..$^{8}$

56. Amy Greenberg, Cause for Alarm: The Volunteer Fire Department in the NineteenthCentury City (Princeton, NJ, 1996), ch. 3; idem, "The Origins of the American Municipal Fire Department: Nineteenth-Century Change from an International Perspective", in Michèle Dagenais, Irene Maver, and Pierre-Yves Saunier (eds), Municipal Services and Employees in the Modern City (Aldershot, 2003), pp. 47-65; Tebeau, Eating Smoke, p. I 30.

57. Christine Meisner Rosen, The Limits of Power: Great Fires and the Process of City Growth in America (Cambridge, 1986); Kevin Rozario, "Making Progress: Disaster Narratives and the Art of Optimism in Modern America", in Lawrence J. Vale and Thomas J. Campanella (eds), The Resilient City: How Modern Cities Recover From Disaster (Oxford, 2005), pp. 27-54.

58. Raymond B. Fosdick, European Police Systems, Donal MacNamara (ed.) (Montclair, NJ, 1969), pp. 370-37I. On the politicized nature of American policing see Roger Lane, Policing the City: Boston I 822-I885 (Cambridge, MA, 1967). On the relationship between social reformers and transnational networking see Daniel Rodgers, Atlantic Crossings: Social Politics in a Progressive Age (Cambridge, MA [etc.], I998). 
Fosdick's influence on research into transnational police management was evident in Charles Reith's classic contrast between English "community policing” and continental autocratic policing. James Richardson's comparative study of policing in Weimar Germany and the United States further reinforced views that the Berlin police, in conforming to a "basic conservatism" fuelled by anti-democratic ideals, pervaded local society beyond the traditional dual-pronged strategy of maintaining order and preserving the peace, which was common in Britain. 59 Indeed, the German "science" of policing (Polizeiwissenschaft), with its origins dating from the seventeenth century, was concerned more generally with the imposition of public decency and morality through the issuing of local ordinances. Thus, German policing, as was also the case with the Austrian, French, and even Scottish experiences, involved the regulation of street lighting and cleansing, firefighting, public health, and, more generally, "the conduct of conduct". These governing principles were evident in the dense handbooks issued by the Berlin and Stuttgart forces during the late nineteenth century, which contrasted the experience of the German constable with that of his English counterpart, especially after the separation of police and fire services in cities like Birmingham and Leicester. ${ }^{60}$

Similarly, in the management of police behaviour, personnel strategies differed somewhat between the English and German models. Whilst English forces increasingly recruited from the skilled industrial class or "clerkocracy", continental policemen were recruited, "almost without exception", from the army. Until the end of World War I, German and Austro-Hungarian forces demanded recruits reach a certain grade within the army, usually corporal rank (Unteroffizier). Up to 80 per cent of recruits in Amsterdam, Rotterdam, and Brussels had military training, albeit chiefly due to military conscription, while the French police gave preference to applicants who had reached the middle-ranking grade of sous-officier. ${ }^{61}$ Moreover, the general structure of a number of "national" police forces, notably the French gendarmerie and the Italian carabinieri, were militaristic, yet limited in their jurisdiction to the countryside, with

59. Charles Reith, The Blind Eye of History (London, 1952), ch. I5; James Richardson, "Berlin Police in the Weimar Republic: A Comparison with Police Forces in the United States", in George Mosse (ed.), Police Forces in History (London, 1975), pp. 79-94; Pierre-Yves Saunier, "Ulysses of Chicago: US Public Administration and the International Scene, I900-1960", in Roy McLeod and Giuliana Gemelli (eds), The Impact of Foundations Work in Europe (Brussels, 2002), pp. II 5 - I 28.

60. Fosdick, European Police Systems, pp. 18-23; F-L. Knemeyer, "Polizei", Economy and Society, 9 (1980), pp. I72-196; Kit Carson and Hilary Idzikowska, "The Social Production of Scottish Policing, 1795-1900", in Douglas Hay and Francis Snyder (eds), Policing and Prosecution in Britain, 1750-1850 (Oxford, 1989), pp. 270-272; Mitchell Dean, Governmentality: Power and Rule in Modern Society (London, 1999), p. 91.

6r. Fosdick, European Police Systems, pp. 199-208. 
the provincial cities policed by institutions like the guardie di città, which were subjected to a complex web of national and municipal regulations. ${ }^{62}$

Although Fosdick emphasized the military discipline in the German and French police, with written regulations outlining in detail the importance of constables adopting "a military posture" and saluting superior officers, he found no similar references in English police handbooks. Thus, although English provincial policing was managed according to a strict disciplinary code that reinforced its institutional transparency, Fosdick noted that the importance of individual police work strengthened the English preference for discretion at the expense of unequivocal obedience and "military smartness": "Certainly, in hard-headed common sense, in ability to meet situations and handle perplexing and unanticipated problems, the ordinary English constable is far superior to the Continental Schutzmann or gardien de la paix." 63

Moreover, in contrast to the subtle relationship between the watch committee and chief constable in Birmingham and Leicester, some continental chief constables complained of their limited powers over disciplinary regulations. Thus, in Stuttgart the Polizeidirektor bemoaned his inability to levy significant fines on the rank and file or dismiss persistent rule-breakers without seeking the approval of the Burgomaster, whilst municipal officials in Rotterdam, Leipzig, and Ulm asserted their "right of interference" in personnel matters. Yet, in practice, the majority of disciplinary cases were dealt with internally by senior officers, and there was little recourse to the approval of elected elites, even in those Prussian royal forces subjected to discipline from state courts. Moreover, clear functionalist agendas existed in the expansive schemes of patrol inspection and the recording of personnel information initiated in English and continental forces, even if the minutiae of recording conventions differed. ${ }^{64}$

Fosdick's "fundamental distinction" between English and continental policing rested on the service's ideology. In the English model, constables were civil employees responsible to the law and civil society, whose primary duty was the preservation of order and prevention and detection of crime. Continental policing, or, more specifically, those forces moulded on the French gendarmerie, was a military rather than a civil model. The continental Schutzmann or gendarme was responsible to the Crown or some other higher authority, rather than the public. His appearance, demeanour, training, and arming made him the physical embodiment of state power and legitimate violence. As "the only official empowered to

62. Jonathan Dunnage, The Italian Police and the Rise of Fascism, I897-1925 (Westport, CT, 1997); Jacques Aubert et al. (eds), L'état et sa Police en France 1789-1914 (Geneva, 1979).

63. Fosdick, European Police Systems, pp. 228-230.

64. Ibid, pp. $258-270$. 
use physical violence in day-to-day dealings with citizens", the continental police officer was distinguished from his English counterpart who, aside from extreme cases of brutality, policed through consent and discretion. ${ }^{65}$

In this context, English policing was increasingly a blue-collar profession in which constables negotiated operational discretion within a general framework of managed autonomy, administrative supervision, and qualified discipline. Like firefighters and other vocations with their own internal labour market, English constables grumbled about the rigours of the job and the hardships associated with a strict disciplinary regime, yet ultimately their accountability to civil society set them aside from the experience of continental police forces, whilst the non-partisan nature of English police administration distinguished it from the overtly politicized "game" of American policing. ${ }^{66}$

\section{CONCLUSION}

This article has demonstrated that the management of disciplined and uniformed public services was not a clear-cut conflict between employers and employees. Nor, however, was management a progressive and rationalizing process spearheaded by "great men" and welcomed with open arms by the rank and file. Rather, as was characteristic of civil society, the management of English police and fire services involved consensual and negotiated tactics, albeit combined with an enduring disciplined and hierarchical regulatory system. Although there were clear disincentives for joining either profession, not least the constraints on individual discretion, neither constables nor firefighters held the objective of "surviving" their "work-life" amidst "the crucible of conflicting class pressures". 67

Certainly during the I870s and I 880 s the work-life of both services was arduous, but there existed an elaborate system of incentives and rewards alongside regular pay and a clearly defined career structure that provided a fair standard of living for long-term employees. Indeed, compared to continental militaristic experiences, the system of material and non-material benefits adopted in English provincial cities provided a clear incentive structure for the development of a professional ethos. Thus, by the interwar years the attraction of a career in either service was evident. Decent pay and a generous pension, combined with access to a representative support network in the Police Federation, helped the police profession evolve and carve out greater autonomy for the rank and file, in stark contrast to the

65. Ibid, p. 200; Emsley, Gendarmes and the State, p. 7.

66. For a similar argument in the context of police unionism, see Joanne-Marie Klein, "BlueCollar Career: Policemen's Perplexing Struggle for a Voice in Birmingham, Liverpool and Manchester, 1900-1919", Crime, Histoire E Societies, 6 (2002), pp. 5-29.

67. Brogden, On the Mersey Beat, p. I65. 
enduring traditions of militaristic obedience within the gendarme model and the partisan influences within American city policing. Even the fire service, with its proud adherence to the naval traditions of discipline and servitude, was slowly opening up to a variety of skilled trades and recognizing the importance of providing a career structure in a similar vein to that of the German brigades, which had positively discriminated in favour of architects and engineers since the mid-nineteenth-century. Consequently, this enabled the militant Fire Brigades Union to infiltrate English brigades during the I930s, before conditions of service and wage bargaining became national issues during World War II. ${ }^{68}$

Yet improvements to working conditions were a trade-off between employers and employees. For instance, although the doctrine of constabulary independence legitimized an expansion in discretion amongst constables, this independence was qualified. The permanence of a hierarchical structure throughout the period restricted a constable's practical autonomy, with the beat constable being subjected to surveillance not only in English cities, but equally on the continent. The firefighter, meanwhile, had virtually no operational autonomy owing to the teamwork skills demanded for firefighting. This ultimately strengthened the authority of senior officers, especially the authoritarian and quasidictatorial chief fire officer who insisted that the rank-and-file firefighter submit to his personal authority.

Constables and firefighters shared overlapping characteristics in their working lives despite differences in funding and managing the two services. Both were subject to strict disciplinary codes and rigorous training and were increasingly expected to display technical proficiency in their duties. Both services also shared similarities in their recruitment practices, masculine cultures, and, in some instances, working conditions. They were also instantly recognizable in their uniforms. Moreover, despite the differences in organizational and personnel structures between English and continental services, the experiences of urban police constables, alongside firefighters, still overlapped in their generic form:

Policemen in London and Paris are alike salaried, full-time officials of the state, under the orders of hierarchical superiors who are ultimately responsible to a minister and to an elected assembly; they are alike bound to obey the law of the land and to prevent the overthrow of the government by unconstitutional means. ${ }^{69}$

How then did these blue-collar workers contribute to the regulation of the industrial city? Both certainly set an example to other working groups through their public behaviour. In England they promoted a specific civic

68. John Horner, "Recollections of a General Secretary", in Bailey, Forged in Fire, pp. 279-358. 69. J.J. Tobias, "Police and Public in the United Kingdom", in Mosse, Police Forces in History, p. 96. 
identity that embodied pride in the locality, adulation for public services, and respect for discipline. Whilst this was a motivating force in continental cities, especially in firefighting, the pressures of state control were more significant, while north American police and fire services developed professional loyalties at an earlier stage than their English counterparts. ${ }^{70}$ Moreover, their visibility in the local community also demonstrated the interdependence of public and private behaviour. Employers did not distinguish between these categories, which indicated that the national and local state considered the policing of private space as equally important as the regulation of public spaces. 